\title{
Rituximab and biosimilars - equivalence and reciprocity
}

This article was published in the following Dove Press journal:

Biosimilars

15 June 2013

Number of times this article has been viewed

\author{
Zaina P Qureshi',2 \\ Jametta S Magwood' \\ Sarveshwari Singh ${ }^{3}$ \\ Charles L Bennett ${ }^{1,2,4}$ \\ 'South Carolina College of Pharmacy, \\ Columbia, SC, USA; ${ }^{2}$ Arnold School \\ of Public Health of the University of \\ South Carolina, Columbia, SC, USA; \\ ${ }^{3}$ Department of Biological Sciences, \\ George Washington University, \\ Washington, DC, USA; ${ }^{4} \mathrm{Hollings}$ \\ Cancer Center, Charleston, SC, USA
}

Correspondence: Charles L Bennett 715 Sumter Street, Suite 3II, Columbia 29208, SC, USA

Tel + I 8037779004

Fax +8037772820

Email bennettc@sccp.sc.edu
Abstract: Cancer is a debilitating disease affecting millions of people daily. Over the years, cancer treatment has advanced in leaps and bounds. Antibodies are important breakthrough therapeutic agents for cancer. These agents, proteins produced by B lymphocytes of the immune system in response to antigens, bind to receptors on cell surfaces so that the antigen-antibody complexes can be recognized and destroyed by phagocytes. While each B cell synthesizes only one kind of antibody, an entire population of different types of B cells and their respective antibodies are produced in response to various antigens to which the organism had been exposed. However, to be useful clinically, substantial amounts of a single antibody must be generated from a single ancestral B cell. These antibodies produced by a specific population of B cells are the monoclonal antibodies that have become the cornerstone of treatment for cancer and many immunologic illnesses. The purpose of this report is to provide an overview of the clinical development of biosimilars in clinical oncology, focusing on rituximab and like biosimilars.

Keywords: rituximab, cancer treatment, biosimilars

\section{Innovations in monoclonal antibody (MAb) production}

MAbs are laboratory-produced molecules engineered to attach to specific defects in cancer cells. MAbs mimic antibodies the body naturally produces. The first MAbs were produced from mouse cells. ${ }^{1,2,3}$ These MAbs were viewed as foreign, and an immune response was generated as a result. In the short term, allergic-type reactions resulted. ${ }^{4}$ Moreover, the antibodies' effectiveness was time-limited until the immune system was primed to destroy the MAbs. Over time, researchers developed mousehuman hybrid MABs - ie, chimeric or humanized antibodies. ${ }^{5}$ Some MAbs are now fully human. Newer approaches involve using fragments of antibodies which may be better able to reach a tumor, making them more effective. ${ }^{4}$ Some MAbs approved by the US Food and Drug Administration (FDA) in the past decade for the treatment of cancer are shown in Table 1.

\section{Rituximab}

Rituximab, a chimeric IgG1 anti-CD20 MAb, is a breakthrough MAb for cancer, rheumatoid arthritis, and a wide range of immunologic illnesses. ${ }^{6,7}$ It has received formal FDA regulatory approvals for treatment of non-Hodgkin lymphoma and chronic lymphocytic leukemia and, in combination with methotrexate, as second-line therapy for adult patients with moderate to severe rheumatoid arthritis. ${ }^{8}$ Rituximab received 
Table I Monoclonal antibodies used to treat cancer

\begin{tabular}{|c|c|c|c|}
\hline MAb name & $\begin{array}{l}\text { Trade } \\
\text { name }\end{array}$ & Used to treat & $\begin{array}{l}\text { Approved } \\
\text { in }\end{array}$ \\
\hline Rituximab & Rituxan $^{\circledR}$ & $\begin{array}{l}\text { B-cell non-Hodgkin } \\
\text { lymphoma }\end{array}$ & 1997 \\
\hline Trastuzumab & Herceptin $^{\circledR}$ & Breast cancer & 1998 \\
\hline Alemtuzumab & Campath $^{\circledR}$ & $\begin{array}{l}\text { Chronic lymphocytic } \\
\text { leukemia }\end{array}$ & 2001 \\
\hline $\begin{array}{l}\text { Ibritumomab } \\
\text { tiuxetan }\end{array}$ & Zevalin $^{\circledR}$ & $\begin{array}{l}\text { B-cell non-Hodgkin } \\
\text { lymphoma }\end{array}$ & 2002 \\
\hline Tositumomab & Bexxar $^{\circledR}$ & $\begin{array}{l}\text { B-cell non-Hodgkin } \\
\text { lymphoma }\end{array}$ & 2003 \\
\hline Cetuximab & Erbitux $^{\circledR}$ & $\begin{array}{l}\text { Colorectal cancer } \\
\text { Head and neck } \\
\text { cancers }\end{array}$ & $\begin{array}{l}2004 \\
2006\end{array}$ \\
\hline \multirow[t]{4}{*}{ Bevacizumab } & Avastin $^{\circledR}$ & $\begin{array}{l}\text { Colorectal cancer } \\
\text { Non-small cell lung } \\
\text { cancer }\end{array}$ & $\begin{array}{l}2004 \\
2006\end{array}$ \\
\hline & & Breast cancer & 2008 \\
\hline & & Glioblastoma & 2009 \\
\hline & & Kidney cancer & 2009 \\
\hline Panitumumab & Vectibix $^{\circledR}$ & Colorectal cancer & 2006 \\
\hline Ofatumumab & Arzerra $^{\circledR}$ & $\begin{array}{l}\text { Chronic lymphocytic } \\
\text { leukemia }\end{array}$ & 2009 \\
\hline
\end{tabular}

its initial FDA approval for marketing in the USA in 1997 and in the European Union in $1998 .^{9}$

\section{Biosimilars}

The Patient Protection and Affordable Care Act (2010) created an abbreviated approval pathway for biological products that are considered to be highly similar (biosimilar) to or interchangeable with an FDA-licensed biological product. ${ }^{10}$ A biosimilar is a biological product that is highly similar to an already regulatory approved biological product, notwithstanding minor differences in clinically inactive components, and for which there are no clinically meaningful differences between the biosimilar and the approved biological product in terms of the safety, purity, and potency. ${ }^{11}$ Through this new approval pathway, biological products are approved based on demonstrating that they are biosimilar to, or interchangeable with, a previously FDA-approved biological product, also termed as a reference product.

The Federal Trade Commission predicts that the availability of biosimilars will significantly reduce biologics' cost and increase their accessibility. ${ }^{12}$ The rationale for encouraging the development of follow-on biologics is to

Table 2 Rituximab and its biosimilars

\begin{tabular}{ll}
\hline Country & Biosimilar \\
\hline USA & Rituxan $^{\circledR}$ and MabThera \\
India & Reditux \\
\hline
\end{tabular}

reduce costs by fostering price competition. The availability of biosimilars is expected to result in savings of between US\$9 billion and US\$12 billion to the Medicare program in the next decade. ${ }^{13,14}$

Since the mid-1990s, physicochemical and functional assays have been used to characterize changes in manufacturing processes for some biologics. Subsequently, animal and clinical studies are employed to demonstrate comparability of the products as well as evaluate their safety and efficacy. Because of several factors, including the larger size and higher degree of molecular complexity of biologic products, the regulatory model of approving biologics may be complicated. In particular, the potential exists for real differences in the active molecules and therefore in the safety and effectiveness of different versions of the same biologic.

The European Medicines Agency (EMA) published general guidelines on biosimilars in $2005^{15}$ and approved its first biosimilar in 2006. ${ }^{16,17}$ Initial EMA guidance suggested product-specific requirements for structural, animal, and clinical studies. Under the draft versions of the 2010 Biologics Price Competition and Innovation Act, biosimilars will have the opportunity to meet a higher standard of similarity to a reference product, allowing pharmacists to make substitutions between biologics without physician intervention. ${ }^{18} \mathrm{~A}$ biologic will be considered interchangeable with a reference product if the developer demonstrates that it can be expected to produce the same clinical result in any given patient and that the risk associated with alternating or switching between the two products is not greater than that involved in continuing to use the reference product.

\section{Reditux $^{\mathrm{TM}}$ - biosimilar rituximab in India}

Biosimilars are increasingly important products in India. ${ }^{19}$ In terms of sales figures, US\$200 million was recorded for sales of biosimilars in India in 2008. ${ }^{20}$ India is a semi-regulated pharmaceutical market, and clinical trials required for regulatory approval of biosimilars in India only require evidence of safety and biologic equivalence. ${ }^{21}$ At US\$6.6 billion worldwide in 2010 sales, rituximab is the largest revenue-producing biologic to enter the world of biosimilar development. ${ }^{22}$ Reditux, the world's first biosimilar MAb for rituximab is a special initiative. It is registered as a copy version of the patented rituximab (termed MabThera ${ }^{\circledR}$ outside of the United States) in India. The anti-CD20 MAb was developed by the Indian generic manufacturer, Dr Reddy's, and is launched with a price of approximately $50 \%$ less than the originator. Both proprietary rituximab (MabThera) and biosimilar 
rituximab (Reditux) have the same clinical indications in India- for lymphoma, chronic lymphocytic leukemia, and rheumatoid arthritis. After the launch of Reditux in India, the manufacturer sought regulatory approvals in other semiregulated countries like Peru. ${ }^{23}$

There are production differences between MabThera and Reditux. The cation exchange chromatography profiles differ. The Indian Regulatory agencies have accepted comparability studies from Dr Reddy's laboratory based on circular dichroism studies. ${ }^{24}$ However, the FDA does not consider circular dichroism studies acceptable for demonstrating comparability. Large molecule biosimilars like rituximab are more complex than small-molecule drugs. It is for this reason they are called biosimilars and not generics. (see Table 2).

\section{Safety of biosimilars - general principles}

One method of studying the safety of biosimilars is to develop a prospective post-approval registry. Developing and maintaining such registries is not easy, particularly if the registry must enroll and follow a large cohort. On the plus side, this model maintains very complete data on exposures, and possibly outcomes, but is extremely expensive to establish and maintain, and very burdensome for health care providers to use..$^{25,26}$

Electronic medical records or administrative claims data present a more common means to measure exposure and outcomes once a product has entered the market. The data are routinely collected, and identification of a group of individuals who received treatment is possible, allowing for comparisons between treated versus untreated patients. ${ }^{26}$

\section{European Union as a model for evaluating biosimilar safety}

In 1986, the European Union enacted legislation that created a legal basis for approval of generic biologicals that was similar to the traditional system used in the United States for small-molecule chemical drugs. ${ }^{27}$ Due to concerns surrounding the active ingredient as well as lack of rigorous scientific literature relating the innovator product to the biosimilars, the legislation was rethought. The European Union reworked its system for approval of biosimilars, with basic provisions for governing "biosimilars." 28 The new process allowed for long-term data follow-up as well as provisions for clinical data to make determinations on interchangeability. ${ }^{29}$ Further, this system involves a combination of primary and secondary legislation and requirements for a guidance process. ${ }^{30}$

Additionally, guidance documents needed to be issued as a collaborative effort between the scientific community, national authorities, expert committees and the industry and pre-clinical as well as clinical research became mandatory. Biosimilars in Europe are not assumed to be fully interchangeable. The current approval system therefore places heavy emphasis on post-marketing testing as well as safety surveillance data. To date, human growth hormone and erythropoietin biosimilar products have been approved, and interferon-alpha has been rejected in Europe. Patents for drugs tend to expire earlier in Europe than in the United States making the regulatory processes for biosimilars a priority concern nationally. The experience of biopharmaceutical companies in Europe who have adopted the revised approval guidelines as well as the other countries with guidelines on biosimilars approval in place could provide a foundation for an effective and efficient approval process that could be used nationally. ${ }^{31-33}$

\section{Approval pathway for Reditux in India}

Dr Reddy's was the first to gain approval for a rituximab biosimilar in Asia, Latin America, and the Middle East. In the case of rituximab, within 3 years of launch of Reditux, the number of patients receiving this therapy increased more than six-fold in India. This widespread use led to patient benefit in this resourcechallenged country where there is a wide income disparity, and individuals bore practically the entire burden of the cost of therapy. Pharmaceutical monopolies do not ensure affordability of drugs even for lifesaving medications in India.

The approval pathway for the rituximab product in India followed a single-arm clinical trial that populated a clinical trial database. The objective response rate of the trial was demonstrated among 67 patients in India. Comparisons were shown with the originator product using literature searches to show similar objective response rates for the same indication. The relatively low sample size was attributed to the price of proprietary Rituxan ${ }^{\circledR}$ or MabThera in India. The number of patients in India receiving proprietary Rituxan was less than 1000 at the time.

In a country like India, for the regulatory agencies to mandate large head-to-head Phase III clinical trials against the proprietary brand was not possible, and rituximab was not considered the standard of care at the time. However, there was an expectation that there would be extensive post-marketing surveillance in which 1000 patients receiving Reditux would be evaluated. Given similar ranges of the response rate in the single-arm trial, as well the confidence intervals between Reditux and rituximab, Dr Reddy's advocated a benefit versus risk consideration for regulatory approval versus a head-to-head comparative trial. ${ }^{34}$ 


\section{Reciprocity of the products}

The large pharmaceutical manufacturer Hoffman La Roche (the manufacturer of proprietary rituximab) supports the development of a regulatory framework for biosimilars and suggests that the approval process be based on the concept of similarity; in comparison with the reference and innovative product with a rigorous head-to-head, high quality non-clinical and clinical evaluations. Extrapolation of safety and efficacy across indications should not be supported without adequately powered clinical trials, but a similar entrance must meet the firm criteria for immunogenicity testing and post-authorization risk management including pharmacovigilance. Hoffman La Roche, the FDA, and Dr Reddy's all highlight the concern that safety is the most difficult aspect in the evaluation of biosimilars. ${ }^{34-36}$

At the production level, each biosimilar should be uniquely identified. Immunoglobulins are highly complex molecules. Any subtle change in any of the clinical parameters might prompt a new biologic or a significant variation in the biosimilar, and it continues even with the mode of action for MAbs. Modes of actions are complex and not at all understood for all monoclonals, particularly for rituximab, which has activity in a wide range of related and unrelated illnesses. Variations in mechanistic pathways for rituximab might contribute differently to its efficacy in different disease states. Demonstration of clinical similarities is challenging, with biomarkers or well established in-vitro potency assays being potentially important adjuncts.

For biosimilars, similarity concerning efficacy and safety with the reference product must be demonstrated in adequately powered clinical trials. Demonstration of clinical similarity is not a straightforward task. Noninferiority alone is not acceptable as an outcome because safety risks might exist and not be recognized. For particular products, different safety margins may need to be accepted for different indications (lower safety margin for multiple sclerosis and higher for lymphoma, for example). The primary objective of regulatory approval clinical trials for biosimilars will be to demonstrate efficacy and safety similarity to the reference product. ${ }^{34}$

\section{Proof of effectiveness - how high will the bar at the FDA be?}

In oncology, the FDA evaluates endpoints of survival, and in some cases (as in accelerated approval), outcomes that are expected to be correlated with survival. ${ }^{33}$ Progressionfree survival is sometimes an accepted outcome, and in other instances it is not accepted. ${ }^{37,38}$ There is no proposed pathway for an accelerated FDA approval of biosimilars based on nonvalidated surrogate endpoints such as response rate.

Activity endpoints such as biomarkers can often be measured faster, cheaper, and with more precision than clinical outcomes..$^{39}$ However, these should not be taken as a sole basis for judging similarity of biosimilars. Similarity in effects on a biomarker will not always predict similarity in effects on clinical outcome. To establish regulatory guidelines it may be more effective to compare the effect of biomarkers in identifying or excluding clinical differences. In immunology, circulating levels of cytokines or inflammatory markers are well established biomarkers that correlate in some instances with clinical outcomes, but not in others. ${ }^{40}$ For B-cell diseases, a potential biomarker is reduction in lymphocyte count; although, this does not directly correlate with the clinical benefit of the drug. ${ }^{41}$ Therefore demonstration of similar effects on an easier measured biomarker should be considered as a minimum requirement in establishing similarity of the biomarker with the reference product, but further rigorous testing should be considered as well.

\section{Extrapolation of safety across indications}

Concomitant medications, patient immune competence, approved dosing and scheduling, and susceptibility of populations to specific toxicities will affect the in vivo efficacy and safety of biosimilars. Also, immunogenicity data in all target populations and target diseases will be needed. When an innovator drug has safety concerns and a second indication where different safety concerns exist, the biosimilar generally should be assessed for safety concerns in both settings. For rituximab in particular, its various modes of action contribute to its clinical benefit in a range of indications and with a wide array of concomitant treatments. Hence, extrapolation of rituximab biosimilar benefit from one disease to another, like rheumatoid arthritis to oncology, involves evaluation of different modes of actions, different effective mechanisms, and a range of host immune status profiles.

Extrapolation from line of treatment, first-line versus relapsed versus refractory, might put patients at risk again due to alterations in their host immune system, with immune compromise being more common with advanced disease. Affected mechanisms such as natural killer cells necessary for antibody-dependent complement-mediated cytotoxicity might be absent among persons with compromised immune systems. ${ }^{42}$ Extrapolation from single agent to treatment to combination treatment is also uncertain due to involvement of a wide array 
of mechanistic pathways as well as drug-drug interactions. It might be possible to extrapolate the benefit of concomitant treatments one at a time in conjunction with the biosimilar under investigation.

Hence, for complex biosimilars, there will always be differences in effects in comparison with the reference product. ${ }^{43}$ Preclinical toxicity studies are essential, but clinical headto-head trials of the biosimilar product versus the reference product will be required to address these differences. The goal will be to demonstrate similarity in safety and efficacy, a result that is difficult to do with small clinical trials. For lifesaving biosimilars where other therapeutic options are limited, a wide confidence interval may be allowed. Similarity needs to be also demonstrated for both safety and efficacy. Surrogate endpoints are acceptable only if a clear and clinically validated correlation exists to the desired endpoint.

\section{Regulatory perspective for the future}

Since 2007, Dr Reddy's Laboratories Ltd, in India has marketed Reditux, for treatment of B-cell non-Hodgkin's lymphoma and, more recently, for treatment of rheumatoid arthritis. But Dr Reddy's is far from the only contender in the generic market. Among the new entrants are Teva Pharmaceutical Industries limited (Petach Tikva, Israel) and Sandoz (Basel, Switzerland), both of whom are involved in comparing the pharmacokinetics and pharmacodynamics of their biosimilar rituximab products, TL011 and GP2013 respectively. ${ }^{44,45}$ Biosimilar versions of other targeted biological therapies for rheumatic diseases have also begun pharmacokinetic and pharmacodynamic testing. ${ }^{46}$

\section{Concluding thoughts}

Under the Patient Protection and Affordable Care Act the FDA was given regulatory authority more than a year ago to develop a new pathway for biosimilars. In 2012, draft guidances were issued for biosimilar product development. ${ }^{47}$

Despite trends forecasting a rise in biologic therapies losing patent protection ( 30 biologics with $\$ 51$ billion annual sales) between 2011 and 2015, IMS health predicted an increased spending pattern on biosimilars in 2015 exceeding $\$ 2$ billion.

Given the expected rate of growth and market share, biosimilars may well exceed past spending patterns within the United States. Added to that the current state-of-the-art techniques which allow for mimicking living organisms used in biologics, provides new incentives for manufacturers to tap into the biosimilars market. Finally, given the cost of the innovator products, cost-savings potential associated with biosimilars makes them attractive not only to payers but patients alike.

Today, some of the world's largest conglomerates have been focusing on the biosimilar business. Since 2011, Samsung has entered the biosimilar market by signing a \$266 million deal with Quintiles to produce biosimilars of drugs like rituximab (Rituxan), adalimumab (Humira), etanercept (Enbrel), and infliximab (Remicade). Samsung was followed by Merck entering a \$721 million deal with Hanwha Chemical. ${ }^{48}$ By 2015, the US market may be awash with less expensive biosimilar versions of MAbs. However, given the issues with complex manufacturing methods and different approval guidelines in various countries, attention must be closely paid to the safety of these agents.

\section{Acknowledgments}

This manuscript was supported by funding from a grant from the National Cancer Institute (1R01CA 102713-01), the Centers for Economic Excellence program of the state of South Carolina, and Doris Levkoff Meddin Center for Medication Safety.

\section{Disclosure}

The authors report no conflicts of interest in this work.

\section{References}

1. Kohler G, Milstein C. Continuous cultures of fused cells secreting antibody of predetermined specificity. Nature. 1975;256:495-497.

2. Schwaber J, Cohen EP. Human x mouse somatic cell hybrid clone secreting immunoglobulins of both parental types. Nature 1973; 244(5416):444-447.

3. Freysd'ottir J. Production of monoclonal antibodies. Methods Mol Med. 2000;40:267-279.

4. Stern M, Herrmann R. Overview of monoclonal antibodies in cancer therapy: present and promise. Crit Rev Oncol Hematol. 2005; 54(1):11-29.

5. Dillman RO. Monoclonal antibodies for treating cancer. Annals Int Med. 1989;111(7):592-603.

6. Coiffier B, Haioun C, Ketterer N et al. Rituximab (Anti-CD20 Monoclonal Antibody) for the Treatment of Patients With Relapsing or Refractory Aggressive Lymphoma: A Multicenter Phase II Study. Blood. 1998;92(6):1927-1932.

7. Sanz I. Indications of rituximab in autoimune diseases. Drug Discov Today Ther Strateg. 2009;6(1):13-19.

8. Rituximab [prescribing information]. Available from: http://www accessdata.fda.gov/drugsatfda_docs/label/2012/103705s5367s53881bl. pdf. Accessed April 4, 2013.

9. EPAR Summary for the Public (MabThera). Available from http:// www.ema.europa.eu/docs/en_GB/document_library/EPAR_-_Summary_for_the_public/human/000165/WC500025815.pdf. Accessed April 4, 2013.

10. The Patient Protection and Affordable Care Act. Available from: http://www.gpo.gov/fdsys/pkg/BILLS-111hr3590enr/pdf/BILLS111hr3590enr.pdf. Accessed April 4, 2013. 
11. www.fda.gov [homepage on the Internet]. Biosimilars. Available from: http://www.fda.gov/Drugs/DevelopmentApprovalProcess/HowDrugsareDevelopedandApproved/ApprovalApplications/TherapeuticBiologicApplications/Biosimilars/default.htm. Accessed April 4, 2013.

12. Emerging health care issues: follow-on biologic drug competition. Washington, DC: Federal Trade Commission, 2009. Available from: http://www.ftc.gov/os/2009/06/P083901biologicsreport.pdf. Accessed April 4, 2013.

13. Simoens S. Biosimilar medicines and cost effectiveness. Clinicoecon Outcomes Res. 2011;3:29-36.

14. Hackbarth GM, Crosson FJ, Miller ME. Report of the Congress: improving incentives in the Medicare program. Washington, DC: Medicare Payment Advisory Commission; 2009.

15. Guideline on similar biological medicinal products. London: European Medicines Agency, 2005. Available from: http://www.emea. europa.eu/pdfs/human/biosimilar/043704en.pdf. Accessed April 4, 2013.

16. Committee for Medicinal Products for Human Use. Available from: http://www.emea.europa.eu/docs/en_GB/document_library/Scientific_guideline/2009/09/WC500003517.pdf. Accessed April 4, 2013.

17. First biosimilar drug gets EU market authorization. Available from: http:/www.euractiv.com/health/biosimilar-drug-gets-eu-market-anews-216541. Accessed April 4, 2013.

18. Issuance of Three Draft Guidance Documents on Biosimilar Product Development. Available from: http://www.fda.gov/Drugs/DevelopmentApprovalProcess/HowDrugsareDevelopedandApproved/ApprovalApplications/TherapeuticBiologicApplications/Biosimilars/ucm291186. htm. Accessed April 4, 2013.

19. Current and future issues surrounding biosimilars. Available from: http://www.gabionline.net/Biosimilars/Research/Current-and-futureissues-surrounding-biosimilars. Accessed April 4, 2013.

20. Dr Reddy's looks to biosimilars for growth. Available from: http:// www.gabionline.net/layout/set/print/content/view/full/1779. Accessed April 4, 2013.

21. www.drugregulations.org [homepage on the Internet]. New Indian Guidelines on Biosimilars. Available from: http://www.drugregulations. org/2012/10/new-indian-guidelines-on-biosimilars.html. Accessed April 4, 2013.

22. Carey K. Biosimilars encircle Rituxan, US debates innovator exclusivity. Nat Biotech. 2011;29,177-178.

23. Indian biosimilars market [webpage on the Internet]. Biosimilar News; 2011. Available from: http://www.biosimilarnews.com/ indian-biosimilars-market. Accessed January 14, 2013.

24. Yang P. Roche-An Innovator's Perspective and Position on Biosimilars. Basel, Switzerland: Roche. Available from: http:/www.roche.com/ irp101005.pdf. Accessed November 17, 2012.

25. Hennessy S, Leonard CE, Platt R. Assessing the safety and comparative effectiveness of follow-on biologics (biosimilars) in the United States. Clin Pharmacol Ther. 2010;87(2):57-159.

26. Zuniga L, Calvo B. Biosimilars: pharmacovigilance and risk management. Pharmacoepidemiol Drug Saf. 2010;19:661-669.

27. Biologics Working Party. Available from: http:/www.ema.europa. eu/ema/index.jsp?curlsym-mpages/contacts/CHMP/people_listing_000009.jsp\&midsym-mWC0b01ac0580028d2c. Accessed April 4, 2013.

28. Biosimilar Medicinal Products Working Party. http://www.ema.europa. eu/ema/index.jsp?curlsym-mpages/contacts/CHMP/people_listing_000024.jsp

29. Wiecek A, Mikhail A. European regulatory guidelines for biosimilars. Nephrol Dial Transplant. 2006; 21(Suppl 5):v17-v20.

30. Gottlieb. Biosimilars: Policy, clinical, and regulatory considerations. Am J Health-Syst Pharm. 2008; 65(Suppl 6):S2-S8.

31. Nowicki M. Basic facts about biosimilars. Kidney Blood Press Res. 2007;30:267-272.
32. Crommelin D, Bermejo T, Bissig M, Damiaans J, Kramer I, et al. Pharmaceutical evaluation of biosimilars:important differences from generic low-molecular-weight pharmaceuticals. Euro J of Hospital Pharmacy Sci. 2005;11(1):11-17.

33. US Department of Health and Human Services, Food and Drug Administration [FDA]. Guidance for Industry: Clinical Trial Endpoints for the Approval of Cancer Drugs and Biologics. Silver Spring, MD: FDA; May 2007. Available from: http:/www.fda.gov/downloads/Drugs/ GuidanceComplianceRegulatoryInformation/Guidances/ucm071590. pdf. Accessed November 18, 2012.

34. Food and Drug Administration. Part 15 Public hearing on approval pathway for biosimilar and interchangeable biological products. Available from: http://www.fdalawyersblog.com/BiosimilarsNov3Transcript. pdf. Accessed April 4, 2013.

35. Reichert JM. Next generation and biosimilar monoclonal antibodies. MAbs. 2011 May-Jun; 3(3): 223-240. Available from: http://www.ncbi. nlm.nih.gov/pmc/articles/PMC3149703. Accessed April 4, 2013.

36. Roche Position on Similar Biological Medicinal Products. Available from: https://www.google.com/url?sasym-mt\&rctsym-mj\&qsym$\mathrm{m} \&$ esrcsym-ms \& sourcesym-mweb \&cdsym-m $2 \&$ cadsymmrja\&vedsym-m0CD8QFjAB\&urlsym-mhttp $\% 3 \mathrm{~A} \% 2 \mathrm{~F} \% 2 \mathrm{Fwww}$. roche.com\%2Froche_position_biosimilars.pdf\&eisym-mFII_ UYzAJIGy8QTrnYDIBA\&usgsym-mAFQjCNHPQYpMEgdTk7CSiqyZWUeqxnOH6g\&bvmsym-mbv.43287494,d.eWU. Accessed April 4, 2013.

37. Fleming TR, Rothmann MD, Lu HL. Issues in using progression-free survival when evaluating oncology products. J Clin Oncol. 2009;27(17): 2874-2880.

38. Wilkerson J, Fojo T. Progression-free survival is simply a measure of a drug's effect while administered and is not a surrogate for overall survival. Cancer J. 2009;15(5):379-385.

39. Siegel JP. Clinical issues innovator industry presentation. EMEA workshop on biosimilar monoclonal antibodies. London: European Biopharmaceutical Enterprises; July 2, 2009. Available from: http://www. emea.europa.eu/docs/en_GB/document_library/Presentation/2009/11/ WC500008483.pdf. Accessed November 18, 2012.

40. Libby P, Ridker PM, MaseriA. Inflammation and atherosclerosis. Circulation. 2002;105:1135-1143.

41. Barnes PJ, Chowdhury B, Kharitonov SA, et al. Pulmonary biomarkers in chronic obstructive pulmonary disease. Am J Respir Crit Care Med. 2006;174(1):6-14.

42. Rossini A. Induction of immunologic tolerance for transplantation. Physiol Rev. 1999;79(1):99-141.

43. Kozlowski S, Woodcock J, Midthun K, Behrman Sherman R. Developing the nation's biosimilars program. $N$ Engl J Med. 2011; 365(5):385-388.

44. Teva Pharmaceutical Industries. TL011 in severe, active rheumatoid arthritis patients. In: ClinicalTrials.gov [website on the Internet]. Bethesda, MD: US National Library of Medicine; 2010 [updated May 14, 2012]. Available from: http:/www.clinicaltrials.gov/ct2/show/ NCT01123070. NLM identifier: NCT01123070. Accessed January 14, 2013.

45. Sandoz. GP2013 in the treatment of RA patients refractory to or intolerant of standard therapy. In: ClinicalTrials.gov [website on the Internet]. Bethesda, MD: US National Library of Medicine; 2011 [updated November 11, 2011]. Available from: http:/www.clinicaltrials.gov/ ct2/show/NCT01274182. NLM identifier: NCT01274182. Accessed January 14, 2013.

46. Kay J. Biosimilars: a regulatory perspective from America. Arthritis Res Ther. 2011;13(3):112.

47. www.fda.gov [homepage on the Internet]. Available from: http://www. fda.gov/NewsEvents/Newsroom/PressAnnouncements/ucm 291232. htm. Accessed on April 4, 2013.

48. Carroll J. Everyone wants in, but with no ground rules, the biosimilar business remains elusive. Biotechnol Healthc. 2011;8(3):12-13. 
Biosimilars

\section{Publish your work in this journal}

Biosimilars is an international, peer-reviewed, open access journal focusing on the manufacture, development and medicinal use of biopharmaceutical compounds considered similar to an innovator agent. Specific topics covered in the journal include: Regulatory issues and pathways; manufacturing processes; chemical composition and

Submit your manuscript here: http://www.dovepress.com/biosimilars-journal
Dovepress

structure; quality and purity; patent issues; bioequivalence and interchangeability; clinical efficacy data; patient perspectives. The manuscript management system is completely online and includes a very quick and fair peer-review system. Visit http://www.dovepress.com/ testimonials.php to read real quotes from published authors. 